\title{
Effect of fungal and bacterial bioagent application on total phenolic content in rice leaves pre-inoculated with Xanthomonas oryzae pv. oryzae (Uyeda and Ishiyama) Dowson
}

\author{
Gokil Prasad Gangwar* and A. P. Sinha \\ Department of Plant Pathology, G. B. Pant University of Agriculture and Technology, Pantnagar- 263145 \\ (Uttarakhand), INDIA \\ *Corresponding author. E-mail: gokil_prasad@ rediffmail.com
}

Received: January 27, 2014; Revised received: May 25, 2014; Accepted: May 30, 2014

\begin{abstract}
Present study was carried out to observe the effect of fungal and bacterial bioagents on total phenolic content in rice leaves pre-inoculated with Xanthomonas oryzae pv. oryzae and on disease severity of bacterial leaf blight of rice. Two commercial formulations of Trichoderma harzianum (PBA-1) and Pseudomonas fluorescens (PBA -2) and four formulations of fluorescent pseudomonads and Trichoderma spp. viz, $P$. fluorescens ( $P f$ 83, rice leaf isolate), fluorescent pseudomonad (FLP 88, rice leaf isolate), T. harzianum (rice leaf isolate), Trichoderma spp. (isolate 40 , isolated from rice field soil) were evaluated. Significantly higher mean value of total phenolic content of rice leaves was observed with the application of bioagent formulations as compared to check (pre-inoculated with $X$. oryzae pv. oryzae), chemical treatment and healthy plant. Maximum mean total phenolic content $(342.22 \mu \mathrm{l} / \mathrm{g})$ in rice leaves was observed with Pf 83, which was followed by PBA-2 $(334.44 \mu \mathrm{l} / \mathrm{g})$ and $T$. harzianum $(330.00 \mu \mathrm{l} / \mathrm{g})$. Decrease in disease severity of bacterial leaf blight was observed with the increase of total phenolic content in rice leaves which resulted in increased grain yield and 1000 grain weight.
\end{abstract}

Keywords: Disease severity, Pseudomonas fluorescens, Rice, Total phenolic content, Trichoderma harzianum, Xanthomonas oryzae pv. oryzae

\section{INTRODUCTION}

Bacterial leaf blight disease in rice caused by Xanthomonas oryzae pv. oryzae is known to occur in epidemic proportions in all rice growing areas of the world, particularly destructive in Asia (Mew et al., 1993 and Anonymous, 2002). Hazardous effects of chemical pesticides have imposed the development of suitable eco-friendly means to manage plant diseases. Attempts have been made to manage the disease by means of bioagents (Vasudevan et al., 2002; Manmeet and Thind, 2002; Nzojiyobiri et al., 2003; Babu and Thind, 2005; Palaniyandi et al., 2006; Gangwar and Sinha, 2010a,b; Gangwar and Sinha, 2012a,b and Gangwar, 2013a,b) to reduce crop losses. Application of some biotic and abiotic inducers has been reported (Van Loon, 1983; Kessman et al., 1990; Kuc, 1995 and Biswas et al., 2003) to induce physical and chemical defenses which may resist infection. Induced resistance in rice plants against Drechslera oryzae was reported with the application of various fungal fluids (Trivedi and Sinha, 1976). Induction in systemic resistance by Pseudomonas syringae pv. syringae in rice against Pyricularia oryzae was also reported by Smith and Matraux (1991). Kumawat et al., (2008) investigated biochemical evidence of defense response in paddy and reported induction of resistance against brown leaf spot disease of rice (Drechslera oryzae) with application of fungal bioagents (T. harzianum and $T$. viride) was due to increase elevated level of soluble proteins and total phenol content. This information implies that the higher total phenolic content for a certain period of time in the host might be associated with defense mechanism. Therefore present investigation was undertaken to observe the effect of application of fungal and bacterial bioagents on total phenolic content in rice leaves pre-inoculated with $X$. oryzae pv. oryzae and on disease severity of bacterial leaf blight.

\section{MATERIALS AND METHODS}

The present experiment was conducted in the glasshouse of Department of Plant Pathology, G. B. Pant University of Agriculture and Technology, Pantnagar.

Glasshouse experiment: Experiment was carried out using susceptible rice cultivar Pusa Basmati-1. Nursery was raised in field plots at Crop Research Center. Plastic pots were filled $3 / 4$ by height with natural field soil and fertilized with NPK (@ 120:60:40 kg/ha). Pots were irrigated for puddling. After puddling, 21 days old seedlings of rice cultivar Pusa Basmati-1 were transplanted in each pot and two seedlings per pot were maintained. Pots were arranged in Randomized Block Design. Regular watering was done by using 
tape water. Three replications were maintained for each treatment.

Mass multiplication of fungal and bacterial bioagents and preparation of formulations: Two commercial formulation of T. harzianum (PBA-1) and $P$. fluorescens (PBA-2) obtained from Bio-control Laboratory, Department of Plant Pathology, G.B. Pant University of Agriculture and Technology, Pantnagar and four formulations of $P$. fluorescens ( $P f$ 83, rice leaf isolate), fluorescent pseudomonad (FLP 88, rice leaf isolate), $T$. harzianum (rice leaf isolate), Trichoderma spp. (isolate 40, isolated from rice field soil) were evaluated for ability to induce accumulation of total phenolics in rice leaf challenged with bacterial leaf blight pathogen. Trichoderma spp. was mass multiplied on barnyard millet: Echinocloa frumentacae (local name: Jhangora) grains. Jhangora grains colonized by Trichoderma were air dried in open shade and ground with the help of Willy Mill to get fine powder. This powder was passed through 50 and 80 mesh sieves, simultaneously to obtain spore powder. Fluorescent pseudomonads were multiplied on King's B broth. The isolates were used to inoculate the flask containing $100 \mathrm{ml} \mathrm{KB}$ broth and incubated on incubator shaker at $150 \mathrm{rpm}$ for $48 \mathrm{~h}$ at $25 \pm 2{ }^{\circ} \mathrm{C}$. Bacterial suspension was then mixed directly with sterilized talc powder (@ 1.2, v/w), air dried and mixed well under sterile conditions. The formulations of fungal and bacterial bioagents were prepared by diluting bacterial cell powder or spore powder with talcum powder $($ mesh $=$ 350 with $95 \%$ whiteness) and $1 \%$ carboxyl methyl cellulose $(\mathrm{CMC})$ to get desired concentration $\left(10^{6} \mathrm{cfu} /\right.$ $\mathrm{g}$ ) of bioagents in the formulation.

Inoculation of pathogen, application of bioagent formulations: Pathogen was inoculated by clipping off the leaf tip @ $10^{6}$ cell $/ \mathrm{ml}$ inoculum (Kauffman et al. 1973) at maximum tillering stage. All bioagent formulations (@10 g formulation/ liter water) and chemical treatment $(0.03 \mathrm{~g}$ streptocycline $+1 \mathrm{~g}$ copper oxychloride /liter water) were applied as foliar spray one week after pathogen inoculation.

Measurement of total phenolic content in rice leaves: Phenols were estimated by the procedure described by Sadasivam and Manickam (1997).

Reagents: (1) Methanol, 80\% (2) Folin-Ciocalteau reagent - commercially available reagent was diluted with distilled water in 1:1 ratio and used. (3) Sodium carbonate, $20 \%$ - prepared by dissolving $20 \mathrm{~g}$ sodium carbonate in $100 \mathrm{ml}$ distilled water.

Extraction of phenols: $1 \mathrm{~g}$ leaf tissue was grinded in 5 $\mathrm{ml} 80 \%$ methanol. The extract was agitated at $70^{\circ} \mathrm{C}$ for 15 minutes. Now this methanolic extract was used for estimation of total phenols.

Procedure: To the $1 \mathrm{ml}$ sample (methanolic extract of rice leaves), $5 \mathrm{ml}$ distilled water was added to make the final volume $6 \mathrm{ml}$. To this $250 \mu \mathrm{l}$ Folin's reagent was added and the mixture was incubated for $3 \mathrm{~min}$ at room temperature. After incubation, $1 \mathrm{ml} 20 \%$ sodium carbonate and $1 \mathrm{ml}$ distilled water were added and the solution was incubated for $1 \mathrm{hr}$ at room temperature. Absorbance was recorded at $725 \mathrm{~nm}$. The amount of total phenols was estimated from the standard curve for tannic acid and expressed as $\mu \mathrm{g}$ phenol $\mathrm{g}^{-1}$ fresh leaf weight.

Data collection: Data was recorded as total phenolic content in rice leaves, at $24 \mathrm{~h}$ before bioagent application and 84 and $168 \mathrm{~h}$ after bioagent application. Disease severity was recorded after 28 days after treatment application. After harvesting, grain yield and 1000 grain weight were recorded.

Statistical analysis: Statistical analysis of the data obtained from field experiment was done using appropriate programme as per the requirement of the experiment. The critical difference (CD) was calculated at $5 \%$ level of significance for comparison of difference between the means of different treatments.

\section{RESULTS}

Effect of bioagent application on total phenolic content in rice leaves: Total phenolic content of rice leaves varied significantly with all treatments at different time of interval (Table 1). Mean total phenolic content of rice leaves at $24 \mathrm{~h}$ before application of treatments was $206.66 \mu \mathrm{l} / \mathrm{g}$ which increased significantly at $84 \mathrm{~h}(306.66 \mu \mathrm{l} / \mathrm{g})$ and $168 \mathrm{~h}$ (341.66 $\mu \mathrm{l} / \mathrm{g})$ after application of treatments. Significantly higher mean total phenolic content of rice leaves was observed with the application of bioagent formulations over check and chemical treatment. Rice leaves inoculated with pathogen exhibited significantly higher mean total phenolic content $(211.66 \mu \mathrm{l} / \mathrm{g})$ as compared to healthy plant $(186.66 \mu \mathrm{l} / \mathrm{g})$. Maximum mean total phenolic content $(342.22 \mu \mathrm{l} / \mathrm{g})$ in rice leaves was observed with $\operatorname{Pf} 83$, which is followed by PBA-2 $(334.44 \mu \mathrm{l} / \mathrm{g})$ and $T$. harzianum $(330.00 \mu \mathrm{l} / \mathrm{g})$. Interaction of total phenolic content in rice leaves with different treatments and time interval was significant. Total phenolic content in rice leaves with all treatments was statistically similar at $24 \mathrm{~h}$ before application of treatments. Significant elevation of total phenolic content in rice leaves was observed at $84 \mathrm{~h}$ after application of treatments as compared to $24 \mathrm{~h}$ before application of treatments with all fungal and bacterial bioagents but the values obtained with chemical treatment, check and healthy plant was statistically equal. Similarly, a significant increase in total phenolic content in rice leaves was observed at 168 after application of treatments as compared to $84 \mathrm{~h}$ after application of treatments with all fungal and bacterial bioagents and chemical treatment however, values obtained with check and healthy plant was statistically equal. Maximum total phenolic content in rice leaves was recorded with $P f 83(418.33 \mu \mathrm{l} / \mathrm{g})$ which is statistically equal to $T$. harzianum $(415 \mu \mathrm{l} / \mathrm{g})$, PBA-2 (405 $\mu \mathrm{l} /$ g) and PBA-1 $(400 \mu \mathrm{l} / \mathrm{g})$ at $168 \mathrm{~h}$ after application of treatments. All the bioagent formulations exhibited significantly higher total phenolic content in rice 
Table 1. Effect of application of bioagent formulations on total phenolic content of rice leaves pre-inoculated with X. oryzae pv. oryzae (Xoo), under glasshouse conditions.

\begin{tabular}{|c|c|c|c|c|}
\hline \multirow{2}{*}{ Treatments } & \multicolumn{4}{|c|}{ Total phenolic content $(\mu \mathrm{l} / \mathrm{g})^{*}$} \\
\hline & $\mathbf{T}_{1}$ & $\mathbf{T}_{2}$ & $\mathbf{T}_{3}$ & Mean \\
\hline Xоo $\times$ FLP 88 & 205.00 & 333.33 & 388.33 & 308.88 \\
\hline Хоo $\times \operatorname{Pf} 83$ & 215.00 & 393.33 & 418.33 & 342.22 \\
\hline Хоo $\times$ PBA-2 & 218.33 & 380.00 & 405.00 & 334.44 \\
\hline Хoo $\times$ Isolate 40 & 211.66 & 346.66 & 386.66 & 315.00 \\
\hline Хоo $\times$ PBA-1 & 206.66 & 351.66 & 400.00 & 319.44 \\
\hline Хoo $\times T$. harzianum & 213.33 & 361.66 & 415.00 & 330.00 \\
\hline Xoo $\times$ Chemical Treatment & 211.66 & 195.00 & 243.33 & 216.66 \\
\hline Check $($ Xоo $)$ & 210.00 & 210.00 & 215.00 & 211.66 \\
\hline Healthy plant & 168.33 & 188.33 & 203.33 & 186.66 \\
\hline Mean & 206.66 & 306.66 & 341.66 & 285.00 \\
\hline \multirow{3}{*}{$\mathrm{CD}$ at $5 \%$} & Time & \multicolumn{2}{|c|}{$=6.77$} & \\
\hline & Treatments & \multicolumn{2}{|c|}{$=11.74$} & \\
\hline & Time $\times$ Treatments & \multicolumn{2}{|c|}{$=20.33$} & \\
\hline
\end{tabular}

*Mean of three replications; $\mathrm{T}_{1}=$ Total phenolic content of rice leaves; $24 \mathrm{~h}$ before treatment application; $\mathrm{T}_{2}=$ Total phenolic content of rice leaves; $84 \mathrm{~h}$ after treatment application; $\mathrm{T}_{3}=$ Total phenolic content of rice leaves; $168 \mathrm{~h}$ after treatment application.

Table 2. Effect of application of bioagent formulations on disease severity of bacterial leaf blight of rice after 28 days after treatment application, grain yield and 1000 grain weight, under glasshouse conditions.

\begin{tabular}{|c|c|c|c|}
\hline Treatments & Disease severity $(\%)^{*}$ & Grain yield /Plant $(\mathrm{g})^{*}$ & 1000 grain weight $(\mathrm{g})^{*}$ \\
\hline Xoo $\times$ FLP 88 & $42.33(40.57)$ & 26.79 & 24.92 \\
\hline Хоo $\times \operatorname{Pf} 83$ & $35.67(36.66)$ & 28.41 & 25.64 \\
\hline Хоo $\times$ PBA-2 & $39.00(38.60)$ & 28.08 & 25.48 \\
\hline Xoo $\times$ Isolate 40 & $42.67(40.78)$ & 25.64 & 24.04 \\
\hline Xоo $\times$ PBA-1 & $41.67(40.18)$ & 27.35 & 25.18 \\
\hline Хоo $\times T$. harzianum & $37.67(37.86)$ & 28.24 & 25.61 \\
\hline Xoo $\times$ Chemical Treatment & $51.50(45.86)$ & 22.87 & 22.75 \\
\hline Check $(X o o)$ & $94.33(76.84)$ & 17.02 & 20.18 \\
\hline Healthy plant & - & 27.68 & 25.02 \\
\hline $\mathrm{CD}$ at $5 \%$ & 6.72 & 2.45 & 1.41 \\
\hline
\end{tabular}

* Mean of three replications; Figures in parenthesis are angular transformed values

leaves as compared to chemical treatment, check and healthy plant at 84 and $168 \mathrm{~h}$ after application of treatments.

Effect of bioagent application on disease severity, grain yield and 1000 grain weight : It is evident from table 2 that all bioagent formulations and chemical treatment exhibited significantly reduced disease severity of bacterial leaf blight of rice over check. Minimum disease severity was recorded with Pf 83 $(35.67 \%)$ which was statistically equal to T. harzianum (37.67\%), PBA-2 (39.00\%), PBA-1 $(41.67 \%)$ and FLP $88(42.33 \%)$. All bioagent formulations, chemical treatment and healthy plant were resulted significantly higher grain yield per plant and 1000 grain weight over check. Maximum grain yield per plant was exhibited by Pf 83 (28.41 g) which was at par with $T$. harzianum (28.24 g), PBA-2 (28.08 g), healthy plant (27.68 g), PBA-1 (27.35 g) and FLP 88 $(26.79 \mathrm{~g})$. Maximum 1000 grain weight was recorded with $\operatorname{Pf} 83$ (25.64 g) which was statistically similar to T. harzianum (25.61 g), PBA-2 (25.48 g), PBA-1 $(25.18 \mathrm{~g})$, healthy plant $(25.02 \mathrm{~g})$ and FLP 88
$(24.92 \mathrm{~g})$.

\section{DISCUSSION}

A rapid accumulation of phenols at the infection site is the first stage of defense mechanism which slows the growth of the pathogen (Matern and Kneusal, 1988). In the present study, significantly increased total phenolic content in leaves of rice plant pre-challenged with bacterial leaf blight pathogen $X$. oryzae pv. oryzae (210, 210 and $215 \mu \mathrm{l} / \mathrm{g})$ was observed as compared to healthy plant $(168.33,188.33$ and $203.33 \mu \mathrm{l} / \mathrm{g})$ at $24 \mathrm{~h}$ before and $84 \mathrm{~h}$ and 168 after application of treatments, respectively. Further significant increase in total phenolic content $(195-415 \mu \mathrm{l} / \mathrm{g})$ of rice leaves was observed when $X$. oryzae pv. oryzae inoculated plant were treated with different fungal and bacterial bioagent formulations (Table 1). Similarly, Kumawat et al. (2008) reported increase level of total phenol content $(3.24,3.45$ and $3.12 \mathrm{mg} / \mathrm{g}$ after 5,10 , and 15 days of inoculation, respectively) due to application of $T$. harzianum and $T$. viride in rice seedling pre-inoculating with brown leaf spot pathogen, 
Drechslera oryzae and induction of resistance against disease was also reported. Minimum disease severity of bacterial leaf blight of rice was observed with the application of $P f 83, T$. harzianum, PBA-2, PBA-1 and FLP 88 (Table 2). Decrease in disease severity of bacterial leaf blight was in accordance to increase in total phenol content $(195-415 \mu \mathrm{l} / \mathrm{g})$ in rice leaves with application of fungal and bacterial bioagents. Increase in grain yield and 1000 grain weight was also observed with increase in total phenolic content (195 - $415 \mu \mathrm{l} / \mathrm{g})$ of rice leaves. Kumawat et al. (2008) reported that disease severity of brown leaf spot rice was negatively correlated with total phenol content due to application of T. harzianum and T. viride. Sivakumar and Sharma (2003) recorded an increase in phenolic content in maize leaf sheaths inoculated with $R$. solani or plants raised from $P$. fluorescens treated seeds. Karthikeyan et al. (2006) also reported induction of phenolics in coconut roots treated with biocontrol agents (Pseudomonas fluorescens, Trichoderma viride and $T$. harzianum against Ganoderma disease and they reported maximum level of phenolics after 9 days of treatment application.

\section{Conclusion}

The present study concluded that total phenolic content in rice leaves pre-inoculated with $X$. oryzae pv. oryzae was increased due to application of fungal and bacterial bioagents. Decrease in disease severity of bacterial leaf blight was observed with the increase of total phenolic content in rice leaves which resulted in increased grain yield and 1000 grain weight.

\section{REFERENCES}

Anonymous (2002). FAO statistic India. File:///A/FAOSTAT Data Base results.com.

Babu, A.G.C. and Thind, B.S. (2005). Potential use of combinations of Pantoea agglomerans, Pseudomonas flourescens and Bacillus subtilis as biocontrol agents for the control of bacterial blight of rice. Annals of the Sri Lanka, Department of Agriculture, 7: 23-37.

Biswas, S.K., Srivastava, K.D., Aggarwal, R., Shelly, P., Singh, D.V. (2003). Biochemical changes in wheat induced by Chaetomium globosum against spot blotch pathogen. Indian Phytopath., 54: 374-379.

Gangwar, G.P. (2013a). Efficacy of different isolates of fluorescent pseudomonads against bacterial leaf blight of rice. Afr. J. Agric. Res., 8(37): 4588-4591.

Gangwar, G.P. (2013b). Field efficacy of formulation of fungal bioagents against bacterial leaf blight of rice caused by Xanthomonas oryzae pv. oryzae (Uyeda and Ishiyama) Dowson. J. Appl. \& Nat. Sci., 5(2): 423-426.

Gangwar, G.P. and Sinha, A.P. (2010a). Comparative antagonistic potential of Trichoderma spp. against Xanthomonas oryzae pv. oryzae. Ann. Pl. Protec. Sci., 18: 458-463.

Gangwar, G.P. and Sinha, A.P. (2010b). Evaluation of fluorescent pseudomonads against Xanthomonas oryzae pv. oryzae causing bacterial leaf blight of rice. Ann. Pl. Protec. Sci., 18: 532-534.

Gangwar, G.P. and Sinha, A.P. (2012a). Comparative antagonistic potential of fungal and bacterial bioagents against isolates of Xanthomonas oryzae pv. oryzae. Ann. Pl. Protec. Sci., 20: 154-159.

Gangwar, G.P. and Sinha, A.P. (2012b). Evaluation of Trichoderma spp. and fluorescent pseudomonads for the management of bacterial leaf blight of rice. Indian Phytopath., 65 (1): 89-91.

Karthikeyan, M., Radhika, K., Mathiyazhagan, S., Bhaskaran, R., Samiyappan, R. and Velazhahan, R. (2006). Induction of phenolics and defense-related enzymes in coconut (Cocos nucifera L.) roots treated with biocontrol agents. Braz. J. Plant Physiol., 18(3): 367-377.

Kauffman, H.E., Reddy, A.P.K., Heisk, S.P.V. and Maraca, S.D. (1973). An improved technique for evaluating resistance of rice varieties to Xanthomonas oryzae. Plant Dis. Rep., 57: 537-541.

Kessman, H., Edwards, R., Geno, P.W. and Dixon, R.A. (1990). Stress responses in alfalfa (Medicago sativa L.) constitutive and elicitor-induced accumulation of isoflavonoid conjugates in cell suspension cultures. Plant Physiol., 94: 227-232.

Kuc, J. (1995). Induced systemic resistance an overview. In: Hammerschmidt, R., Kuc, J. (ed.), Induced Resistance to Disease in Plants. Kluwer Academic Publishers, Dordecht, the Netherlands. pp.182.

Kumawat, G.L., Biswas, S.K. and Srivastava, S.S.L. (2008). Biochemical evidence of defense response in paddy induced by bio-agents against brown leaf spot pathogen. Indian Phytopath., 61 (2): 197-203

Manmeet, M. and Thind, B.S. (2002). Management of bacterial blight of rice with bioagents. Plant Dis. Res., 17(1): 21-28.

Matern, U. and Kneusal, R.E. (1988). Phenolic compounds in plant disease resistance. Phytoparasitica, 16:153-170.

Mew, T.W., Alvarez, A.M., Leach. J.E. and Swings. J. (1993). Focus on bacterial blight of rice. Plant Dis., 77 (1): 5-12

Nzojiyobiri, J.B., Xu, T., Song, F.M. and Shen, Y. (2003). Resistance induced by Trichoderma harzianum NF9 against Magnaporthe grisea and Xathomonas oryzae pv. oryzae in rice. Chinese Journal of Biological Control, 19(3):111-114

Palaniyandi, V., Immanuel, J.E., Gnanamanickam, S.S. and Thomashow, L. (2006). Biological control of rice bacterial blight by plant associated bacteria producing 2,4diacetylphloroglucinol. Canadian Journal of Microbiology, 52(1): 56-65.

Sivakumar, G. and Sharma, R.C. (2003). Induced biochemical changes due to seed bacterization by Pseudomonas fluorescens in maize plants. Indian Phytopath., 56:134137.

Smith, J.A. and Metraux, J.P. (1991). Pseudomonas syringae pv. syringae Induces systemic resistance to Pyricularia oryzae in rice. Physiol. Mol. Plant Pathol., 39: 451.

Trivedi, N. and Sinha, A.K. (1976). Resistance induced in rice plants against Helminthosporium infection by treatment with various fungal fluids. J. Phytopathol., 86: 335-344.

VanLoon, L.C. (1983). The induction of pathogenesis related proteins by pathogen and specific chemicals. Neth. J. Plant Pathol., 89: 265-73.

Vasudevan, P., Kavitha, S., Priyadarisini, V.B., Babujee, L. and Gananamanicka, S.S. (2002). Biological control of rice disease. Crop Dis., 34: 11-23. 